\title{
Embung Development Program Impact Evaluation in Banyumas District, Central Java
}

\author{
Novita Wijayanti ${ }^{1}$, Hardi Warsono ${ }^{2}$, Yuwanto $^{3}$, Teguh $^{4}$, Kismartini $^{4}$ \\ \{novita.wijayanti@dpr.go.id ${ }^{1}$ \} \\ Universitas Diponegoro, Indonesia ${ }^{1,2,3,4}$
}

\begin{abstract}
This Research conducted by researchers currently aims to analyze and describe the impact of the policy on the development of Embung building program located in Banyumas District, Central Java province. By using methods of analysis of the impact based on Patton, Sawicki and Clark [1] by comparing the achievement of before and after comparisons, the before and after development policy program was implemented in Banyumas District. To see this, researchers use PDRB data over the prevailing and constant prices especially in agriculture, forestry and fisheries sectors. The results showed that the expected impact of an Embung development in Banyumas District to be able to improve agricultural sectors at the time before and after the construction of Embung has not been optimal. Because the increase in the percentage of 2018-2019 in agriculture sector was still very small, resulting in economic growth rate decreased from the previous year. Moreover, the social welfare of the community in Banyumas District is low compared to other districts in Central Java province.
\end{abstract}

Keywords: Policy Effect Evaluation, Before and After Comparison, Embung Development, Banyumas District, PDRB

\section{Introduction}

Water is a resource and determinant factor that determines the performance of the agricultural sector, because there is not a single crop of agriculture and livestock that does not require water. Although the role is strategic, but water management is still far from the expected, so that the proper water is a one-time farmer transformed into a disaster cause for farmers. The indicators, in the dry season, the fields and rice fields are often drought and vice versa in rainy season, fields and many fields are flooded with water.

In quantity, the problem of water for agriculture, especially in dry land, is a matter of inconsistency of water distribution between necessity and supply according to time (temporal) and place (partial). The issue became increasingly complex, complicated and difficult to predict because water supply depends on the spread of rainfall throughout the year, the spread is uneven even in the rainy season though. Therefore, it is necessary to use appropriate technology, inexpensive and applicable to regulate water availability in order to fulfill the needs of water (water demand) increasingly difficult to do with natural manners. The technology of Embung or Tandon (Water Tank) is one of the promising options because of its simple technology; the cost is relatively cheap and can be reached by the ability of farmers.

Embung or Tandon water (Water Tanks) is a micro-sized reservoir in a small farm reservoir built to accommodate the excess of rainwater in the rainy season. The water that is accommodated is then used as a source of complementary irrigation for agricultural 
commodities cultivation of high economic value (high benefit crops) in the dry season or in the time of rainfall increasingly rare. Embung or Tandon water (Water Tanks) is one of the waters harvesting techniques (water harvesting) that is suitable in all kinds of agroecosystems. In the swampland called Pond that serves as a shelter water drainage when excess water in the rainy season and as a source of irrigation water in the dry season.

Embung Village is one of the four priority programs of village funds. The government allocated from IDR 200 million to 500 million for development per unit of village, which serves as a means of irrigation. Village Pools aka water containers on a large scale are one of the four priorities of village funds confirmed by the Ministry of Rural Development and transmigration. This has also been emphasized by theory from Rusydi [2]. Embung building Program is get very good reception from the Indonesian villages.

Data from Ministry Village mentioned, from 15 thousand Village development priorities currently there are 7,440 villages desperately need to develop water infrastructure to bury the rice fields that they have. Because agriculture is the primary, field that support the villages. Therefore, the construction of Embung answers the issue of most villages. In just a few months, this priority has been in the campaign, already 628 Embung's and awakened in various villages in Indonesia. This shows how an Embung is indeed needed. The Program also received strong support from the Ministry of Agriculture. Until now most of the village in Indonesia is still making agriculture as a part of living the economy of citizens. Based on 74,754 villages are across Indonesia, as many as 82.77 percent of the agricultural land. The number most new can be executed 1.4 times a year. The reason is, that water shortages are therefore Embung program to the village's priorities.

Fulfillment of water needs will create economic leap because they can increase the volume and agricultural products. Which in the end can take the poverty of the people in the village? Because of the construction of a new Embung program, execute in this region.

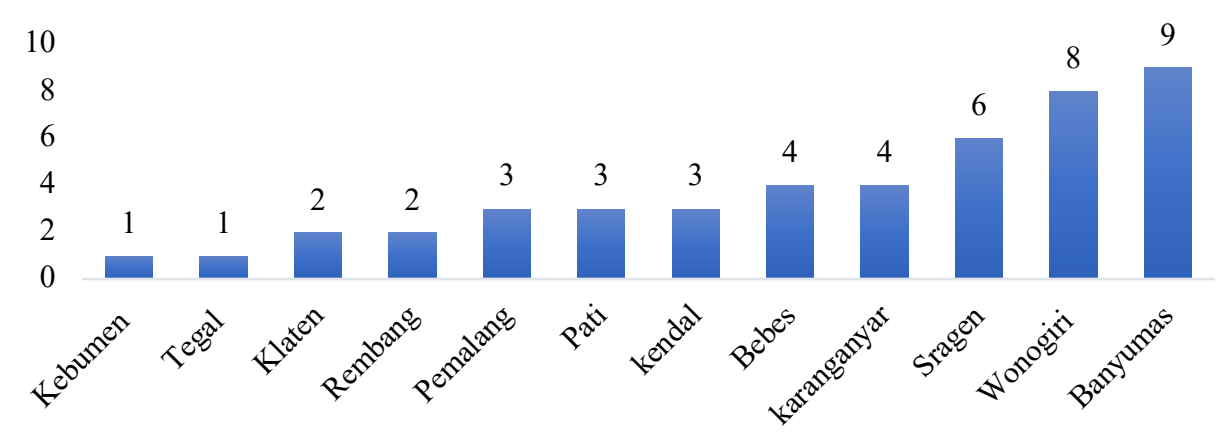

Fig. 1. Number of Embung in District/City of Central Java Province. Source: PSDA of Central Java Province 2016.

\section{Literature Review}

There are some opinions from experts below that can be a reference in understanding the meaning of public policy: Dye [3] he defined the public policy as follows: "Public policy is whatever the government choose to do or not to do" (public policy is any government choice to do something or not do something). According to Dye [4], if the government chooses to do 
something, then of course there is purpose, because public policy is the "action" of the government. If the government chooses not to do something, it is a public policy, which is of course a purpose.

Another definition given by Hogwood and Gunn [5] in his book, Policy Analysis for The Real World, stated that public policy is a set of government actions designed to achieve certain outcomes. Besides, Hogwood and Gunn [6] mentioned the ten uses of the term "policy" in the modern sense as a label for a field of activity, as a general-purpose expression or an activation that is expected, as a specific proposal, as a government decision, as a formal authority, as a program, as an output, as a result, as a theory or model.

According to Landau [7] in his trial that public policies are "Public policy" as other forms of political analysis, uses metaphors or models as devices to explore the unknown and possibly unknowable world of politics. Where it can be interpreted as a public policy as another form of political analysis is using metaphors or models as a device to explore an unknown world and perhaps a politically unknown.

According to Campbell [8], public policy was a sanctioned action that leads to a specific purpose directed at a specific, interconnected issue affecting most community citizens. According to Cairney [9], public policy was a decision made by the State, especially the Government, as a strategy to realize the purpose of the country concerned. Public policy is a strategy to deliver people in the early days, entering the community during the transition, to go to the community desired.

According to Pülzl and Treib [10] mentioned that it was concluded that public policy is a decision made or chosen to be taken by a government agency. Both officials and government agencies who are guidelines of guidance or instruction for each government apparatus, so as to achieve the smoothness and alignment in achieving the objectives of the policy in fact, the policy is often interpreted with other terminology such as objectives, programs, decisions, laws, provisions, proposals and great designs. Public policy is often associated with the government's decision or decree to do an action that is deemed to have a good impact on its citizens lives.

\section{Research Method}

According to Patton, Sawicki and Clark [1] in a book entitled Basic Methods of Policy Analysis and Planning. According to what was expressed by Fischer and Miller [11] one of the methods that can be used to measure the success of policy performance is before and after comparisons. This approach compares the conditions (people or residents of an area) before and after the program (actual post program data) to the target group. In addition, this approach can also be used to compare community conditions after the program is executed (actual post program data) with the community, that does not run the program or policy. Researchers use PDRB data over the prevailing and constant prices especially in agriculture, forestry and fisheries sectors.

\section{Result and Discussion}

In view of a success or failure of the impact of Program of an Embung development policy in Banyumas District, researchers use BPS data from the results of the gross domestic 
product achievement (PDRB) because of prevailing and constant prices. National gross domestic product and Gross Regional Domestic Product known as (PDRB) at regional level (provinces) describe the ability of an area to create benefit at a given time. To develop GDP and PDRB used two approaches, namely business and expenditure. Both present value-added data composition according to economic activity source (business field) and according to the component of its use.

The gross domestic product or its aggregate derivatives are presented in 2 (two) versions of the assessment, which is based on the "prevailing price" and on the basis of "constant price". Referred to as the price is valid because the whole aggregate is assessed by using the price in the current year, while the constant price of the assessment is based on the price of a certain base year, in this publication is used in the price in 2010. Gross domestic product growth rate is derived from GDP calculations because of constant price. The growth rate shows the aggregate development of revenue from one particular time to the previous time.

Gross domestic product of the prevailing price in the agricultural, forestry and fisheries sectors at the time before the impact of the land development in Banyumas District can increase the PDRB on the basis of prevailing price in agriculture, forestry, and fisheries sectors annually. This can be seen in 2018-2019 results of agricultural, forestry, and fisheries sector of PDRB because of the price occurred slightly increased from the year before the period of construction of the wild in Banyumas District.

And when viewed from the percentage of the development impact of Embung land (Water Tank) that has been implemented by the Government of Banyumas District in the agriculture, forestry, and fisheries sector the increase is not too high, where the average annually can only increase $1 \%$ of the PDRB from the previous years. So does the PDRB over constant price.

The impact of an Embung (Water Tank) development in Banyumas District on agriculture, forestry, and fisheries sectors in 2018-2019 showed little increase compared to the previous year when an Embung (Water Tank) development policy program had not been implemented in Banyumas District. It is not optimal that an Embung (Water Tank) development Policy program implemented by the Government of Banyumas District, so it has an effect on increasing the rate of economic growth today.

The impact of an Embung (Water Tank) building program policy implemented by the Government of Banyumas District is currently not able to help increase the rate of economic growth. Where the impact was made after the construction of an Embung (Water Tank) in Banyumas District in 2018-2019, the rate of economic growth of society decreased by $0.13 \%$ from the previous year to $6.32 \%$.

The expected impact of the existence of an Embung (Water Tank) building to improve the welfare of farmers in Banyumas District has not been seen in real life. The pace of declining economic growth and District Banyumas is currently in category 14 red Districts with the lowest level of community welfare in the province of Central Java to be a picture in the field. This is expected impact of an Embung (Water Tank) construction to improve the welfare and economy of farmers and communities in Banyumas District has not been able to be realized optimally.

These 14 Districts in Red have a poverty line over the province and the national as well as Banyumas District including in 14 districts that are in the red zone of poverty in the province of Central Java. The impact of an Embung (Water Tank) development policy program that is expected to improve the social welfare and Economic Community of Banyumas District has not been perceived and depicted in the field, because until now the poverty or welfare level of society is still low under the national and Central Java Province. 
Where the index of poverty severity (P2) in Banyumas District in 14 red is currently the highest among the 13 other districts that belong to the red zone in the current province of Central Java. The Poverty Severity index (P2) of Banyumas District is currently 0.67\%, located above Central Java Province of $0.3 \%$.

\section{Conclusion and Suggestion}

Evaluation analysis result of the impact of an Embung (Water Tank) development program in Banyumas District has been completed. There are several conclusions that can be known as follows:

a) The impact of an Embung (Water Tank) building program policy conducted by the Government of Banyumas District has not been able to improve the welfare of the society's socio-economic conditions today.

b) With the development of an Embung (Water Tank), the impact can increase the PDRB because of fatty and constant prices in agriculture, forestry, and fisheries sectors until now the results are not optimal. Because of an Embung (Water Tank), the impact of the increased is large enough, but in fact, the outcome of the percentage field is still very small.

c) Further impacts expected from the development of an Embung (Water Tank) could drive the rate of economic growth in Banyumas District is by this time does not occur. Because of the current rate of economic growth decreased compared to the year before of the construction of an Embung (Water Tank) in Banyumas District.

d) Likewise, in the end of the building of an Embung (Water Tank) can give on to the improvement of social welfare of the community in Banyumas District cannot be realized.

Because until now the government of Banyumas District is, still in the territory of the red, zone that gases higher poverty than the province and national. So that it can be said the building of an Embung (Water Tank) that is done by the government until now has not helped the existence of the inhabitants of Banyumas District.

An Embung (Water Tank) development Program policy is a major supporting activity in agricultural business through the function of irrigation water supply to realize food sovereignty. In respect of this, all relevant agencies are directly or indirectly able to work with responsibility that is oriented towards the interests of the Community and agricultural affairs. Community participation is very necessary in the implementation of this activity, next to the beneficiaries of the agricultural area development activities to remain able to maintain physically the building of the land in their respective areas, so it is expected that food sovereignty in each beneficiary can be realized immediately.

\section{References}

[1] C. V. Patton, D. S. Sawicki, and J. J. Clark, Basic methods of policy analysis and planning. 2015.

[2] K. M. Desa, D. I. K. Takalar, and H. M. Rusydi, "Pengaruh Alokasi Dana Desa (ADD) Terhadap Kesejahteraan Masyarakat Desa Di Kabupaten Takalar,” J. Ekon. Balanc., 2012.

[3] T. R. Dye, Understanding Public Policy. 2005.

[4] T. R. Dye, Understanding Public Policy. 2016.

[5] B. W. Hogwood and L. A. Gunn, "Chapter 2: Analysing Public Policy," in Policy Analysis for 
the Real World, 1984.

[6] B. Hogwood and L. Gunn, "Why 'perfect implementation' is unattainable," Policy Process. A Read., 1993.

[7] M. Landau, "On the Concept of a Self-Correcting Organization," Public Adm. Rev., 1973.

[8] J. L. Campbell, "Ideas, politics, and public policy," Annual Review of Sociology. 2002.

[9] P. Cairney, Understanding Public Policy. 2012

[10] H. Pülzl and O. Treib, "Implementing public policy," in Handbook of Public Policy Analysis: Theory, Politics, and Methods, 2017.

[11] F. Fischer and G. J. Miller, Handbook of public policy analysis: Theory, politics, and methods. 2017. 